\title{
Short term variability in larval fish assemblages of the Sydney shelf: tracers of hydrographic variability
}

\author{
Kimberley A. Smith ${ }^{1, *}$, Mark T. Gibbs ${ }^{2,3}$, Jason H. Middleton ${ }^{2}$, Iain M. Suthers ${ }^{1}$ \\ ${ }^{1}$ School of Biological Science, University of New South Wales, Sydney, New South Wales 2052, Australia \\ ${ }^{2}$ School of Mathematics, University of New South Wales, Sydney, New South Wales 2052, Australia \\ ${ }^{3}$ Department of Marine Science, University of Otago, PO Box 56, Dunedin, New Zealand
}

\begin{abstract}
The among-and within-night changes in the vertical and horizontal distribution of ichthyoplankton assemblages across the Sydney continental shelf, SE Australia, were examined in relation to concurrent changes in hydrography. Of the environmental factors examined, spatial position (sampling depth, distance from shore), water temperature and sampling depth relative to the base of the mixed layer gave the best explanation for variability in assemblage distributions. There was good agreement between observed changes in ichthyoplankton distributions and among-night variability in the crossshelf temperature and current fields. Ichthyoplankton assemblages functioned as short term, biological tracers of hydrographic variability. Our observations suggest several cross-shelf advective processes, including a recirculation cell over the shelf, could retain passively drifting ichthyoplankton within the shelf region and also minimise longshore drift. The multivariate analysis used was an effective method of examining patterns within and between large, highly variable biological and environmental data sets.
\end{abstract}

KEY WORDS: Ichthyoplankton - Hydrography $\cdot$ Biological tracer $\cdot$ Larval retention $\cdot$ Multivariate

\section{INTRODUCTION}

Local hydrodynamics are often sufficient to explain ichthyoplankton distributions (e.g. Frank et al. 1992, Sabates \& Maso 1992, Olivar \& Shelton 1993, Olivar \& Beckley 1994, Lochmann et al. 1997). In addition, recruitment patterns of post-larvae indirectly implicate the importance of physical processes in larval advection (e.g. Cowen 1985, Polacheck et al. 1992, Castillo et al. 1994, Fechhelm et al. 1994, Sponaugle \& Cowen 1996, Jenkins et al. 1997).

The influence of advective processes on ichthyoplankton assemblages is dramatically illustrated in the coastal zone, where ichthyoplankton responses to dynamic events are often consistent with passive drift. In particular, many physical mechanisms have been

•E-mail: marsci@unsw.edu.au proposed to retain shelf-spawned larvae within continental shelf regions. For example, in the Californian Current system, pelagic spawning of shelf species corresponds to a period of wind driven, onshore surface flow, thus retaining buoyant eggs and larvae within the coastal zone (Parrish et al. 1981). In the NW Mediterranean, a shelf break salinity front functions as a barrier to offshore dispersal of shelf species and may concentrate larvae in the productive frontal zone (Sabates \& Olivar 1996). In the Middle Atlantic Bight, shelf spawned larvae may be transported southward by shelf flows, become entrained in the northward flowing Gulf Stream and may finally be returned to the shelf by regular, but unpredictable, shoreward intrusions of warm core eddies (Hare \& Cowen 1991, Cowen et al. 1993). Dynamic events in the coastal ocean represent significant advective forces despite the fact that they are often of relatively short duration, compared with most ichthyoplanktonic durations. It 
is instructive to examine the response of ichthyoplankton communities to local circulation processes because of the considerable influence that short term hydrodynamic variability may have on overall larval dispersal.

Ichthyoplankton assemblages of the SE Australian continental shelf have been examined in several recent studies (Gray et al. 1992, Gray 1993, Gray 1996a,b, Dempster et al. 1997, Smith \& Suthers 1999). The community is characterised by high taxonomic diversity (>110 families) and considerable assemblage variability over short (daily, Dempster et al. 1997) and long (monthly, Smith \& Suthers 1999) time periods. The responses to wind and ocean forcing in this region can result in rapid hydrographic changes to both near-surface and interior waters over the shelf. However, the short term response of subsurface ichthyoplankton assemblages, which includes the majority of ichthyoplankton in the shelf region, to hydrographic changes is yet to be examined. Short term, advective processes may account for much of the previously observed, unexplained, ichthyoplankton variability in the region (Gray et al. 1992, Gray 1993).

This study aimed to assess the short term (nightly) impact of large scale $(\mathrm{km})$ physical processes on Sydney shelf ichthyoplankton. Sampling was timed to coincide with a period of typically high East Australian Current activity in the region. The approach of the present study differs from many previous investigations of shelf ichthyoplankton assemblages in that we concurrently considered horizontal and vertical distributional patterns, and also compared these biological patterns with hydrological gradients in the same dimensions.

\section{Oceanography of the Sydney region}

Variability of the cross-shore current and density fields over the narrow $(-30 \mathrm{~km})$ Sydney shelf is primarily associated with 3 dynamical processes, namely: the East Australian Current (EAC), the response to the local wind stress and the unforced coastal-trapped waves (CTWs) which propagate northwards along the NSW coast. Recent studies have shown that Sydney shelf and slope waters respond differently to each of these forcing processes (Griffin \& Middleton 1991, McClean-Padman \& Padman 1991, Gibbs et al. 1998).

South of around $32^{\circ} \mathrm{S}$, the EAC is in the form of a recirculating eddy field containing both warm and cold-cored meso- and sub-meso-scale edies and filaments (hereafter referred to as EAC features). Most energetic of these features are the warm-core, anticyclonic, meso-scale eddies with diameters of around $100 \mathrm{~km}$ (Nilsson \& Cresswell 1981) (Fig. 1a). Typically,

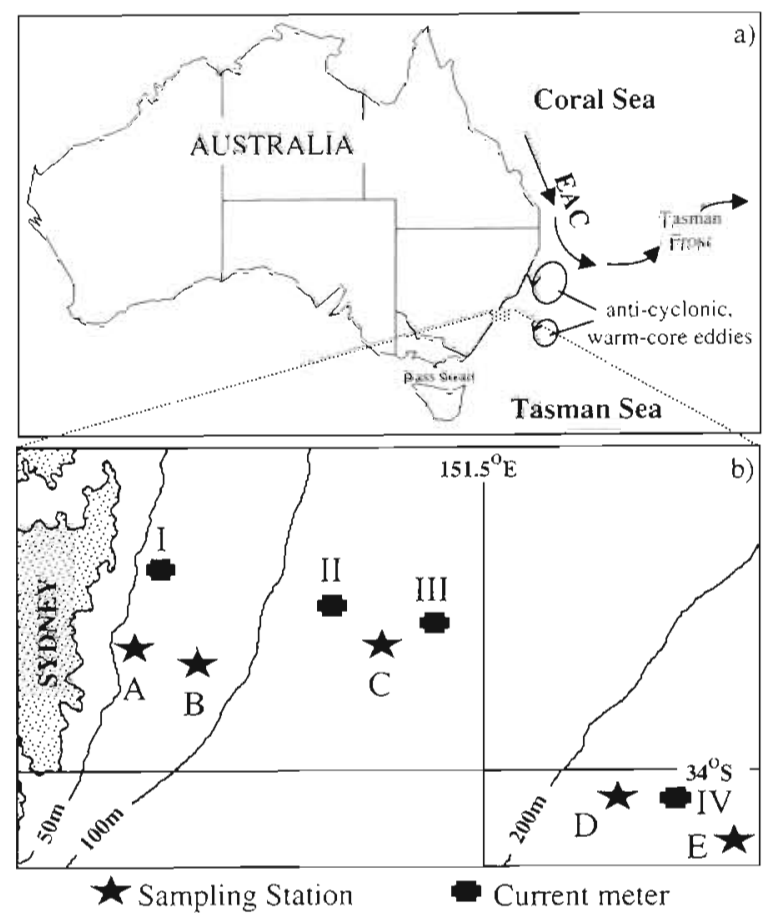

Fig. 1. (a) Schematic of major features of East Australian Current (EAC) system; (b) Sydney shelf and cross-shelf transect. showing ichthyoplankton sampling Stns A to $E_{\text {, and current }}$ meter moorings I to IV

2 or 3 such eddies concurrently exist in the western Tasman Sea. These sporadically intrude into Sydney shelf and slope waters. Strong southward flowing outer shelf and slope currents are often associated with these intrusion events, and the shelf and slope cross-shore temperature, and hence density, fields are significantly altered as isotherms tilt up towards the coast (Gibbs et al. 1998). The evolution of transient shelf-break-fronts have also been associated with these warm intrusion events (Condie 1995). Cold, nutrient-rich waters can also be uplifted into the outer shelf region by small, cold-core EAC eddies in a process similar to the nutrient enrichment of US east coast waters by Gulf Stream instabilities (Csanady 1989, Gibbs et al. 1997).

By contrast, adjustments of the isotherms in the nearshore zone (defined here as from the coast out to a distance of an internal Rossby radius, around $5 \mathrm{~km}$ in summer) are primarily in response to local wind stress (Griffin \& Middleton 1991, Gibbs et al. 1998). Hence, nearshore downwelling and upwelling events occur in response to northward and southward local winds, respectively, although the magnitude and response time of nearshore temperature field adjustments are also influenced by the offshore EAC field. For example, particularly strong transient upwelling states may be produced by the concurrent action of an intruding 
EAC warm feature and southward, upwelling favourable local winds (Gibbs et al. 1998). Free propagating CTWs generated at the eastern end of Bass Strait (south of Sydney) and along the southern NSW coast have been shown to account for a significant amount of the background variability of barotropic currents in the Sydney nearshore zone (Griffin \& Middleton 1991). However, the efficiency of this process as upwelling/downwelling forcing processes in the NSW coastal ocean is yet to be determined.

Other processes which influence the cross-shore density field across the Sydney shelf are the seasonal development of the summer mixed layer and rapid, transient adjustment of the mixed layer depth in response to strong local winds, in particular northward winds associated with atmospheric cold-fronts which propagate northwards along the NSW coast. Baroclinic tides have also been shown to produce semi-diurnal period vertical oscillations of up to $15 \mathrm{~m}$ in the base of the mixed layer in the nearshore zone (Gibbs \& Middleton 1997).

Nearshore current velocities off Sydney have a long term mean of 0.1 to $0.2 \mathrm{~m} \mathrm{~s}^{-1}$ southward, although fluctuations associated with northward and southward currents pulses of 0.2 to $0.3 \mathrm{~m} \mathrm{~s}^{-1}$ occur regularly (Middleton 1987). Over the outer shelf and slope, longshore currents are predominantly southward in response to EAC forcing and velocities may exceed $1 \mathrm{~m} \mathrm{~s}^{-1}$. Crossshelf currents are typically 10 times smaller than longshore flows.

\section{MATERIALS AND METHODS}

Collection of data. Full details of ichthyoplankton sampling methods and processing of samples may be found within Smith \& Suthers (1999). Briefly, data were collected during 2 cruises, in January and April of 1994, aboard the RV 'Franklin'. On both cruises, biological data were collected from 5 stations along a cross-shelf transect adjacent to Sydney, New South Wales, Australia. Oceanographic data were collected along a similar transect. The transect began $2.7 \mathrm{~km}$ offshore and ended $40 \mathrm{~km}$ from the coast. Plankton sampling Stns A, B and C were within shelf waters (bottom depths less than $150 \mathrm{~m}$ ). Stn D was at the shelf break, (bottom depth $250 \mathrm{~m}$ ), and Stn E occurred over the continental slope (bottom depth $600 \mathrm{~m}$ ) (Fig. 1b, Table 1). The transect was sampled January on 22, 23 and 25. between 20:30 and 05:00 h. Sampling also occurred on April 5, 6, 7 and 8, between 19:00 and 06:00 h. The order of sampling was from Stn $A$ to $E$ on all nights except April 8, when sampling began at Stn E and ended at Stn A. Some locations were not sampled on April 7 due to bad weather. Sunset and sunrise were at
Table 1. Location, bathymetry and depth intervals for each ichthyoplankton sampling station

\begin{tabular}{|ccccccc|}
\hline Stn & $\begin{array}{c}\text { Distance } \\
\text { offshore } \\
(\mathrm{km})\end{array}$ & $\begin{array}{c}\text { Bottom } \\
\text { depth } \\
\text { (m) }\end{array}$ & \multicolumn{2}{c|}{ Deepth of sampling intervals (m) } \\
\hline A & 2.7 & 67 & $40-50$ & $30-40$ & $15-30$ & $0-1$ \\
B & 7.3 & 83 & $60-70$ & $40-60$ & $15-40$ & $0-1$ \\
C & 16.4 & 130 & $80-120$ & $40-80$ & $15-40$ & $0-1$ \\
D & 32.8 & 250 & $80-120$ & $40-80$ & $15-40$ & $0-1$ \\
E & 40.0 & 600 & $80-120$ & $40-80$ & $15-40$ & $0-1$ \\
\hline
\end{tabular}

approximately 20:00 and 06:00 h in January, and 17:45 and 06:00 h in April, respectively.

Within-night variability during the night of April 9 was examined by repeated sampling at Stns B and C. Stns B and C were each sampled 4 times between 19:00 and 05:00 h, alternating between stations throughout the night.

Surface plankton samples were collected using a 75 $\times 75 \mathrm{~cm}$ square mouth net $(330 \mu \mathrm{m}$ mesh $)$, fitted with a General Oceanics flow meter. Two surface hauls, each of 6 min duration, were conducted at each station. Near-surface temperature and salinity were recorded by shipboard instruments at a depth of $4 \mathrm{~m}$.

Subsurface plankton samples were collected by a multiple, opening and closing net (an 'EZ net'), with a square mouth of $1 \mathrm{~m}^{2}$ and mesh size of $330 \mu \mathrm{m}$. The net was fitted with temperature, conductivity and depth sensors and 2 General Oceanics flow meters-one inside and one outside the net mouth. Real time data was communicated to an operator onboard ship who electronically triggered each net release. Three depth strata were each sampled by a single haul at each station, and actual sampling depths varied according to water depth at each station (Table 1). Subsurface haul durations were $10 \mathrm{~min}$ and obliquely sampled each depth strata.

In addition to nightly hydrographic data collected by EZ sensors, day time hydrographic data was collected by deployment of a Neil-Brown CTD at up to 11 locations along the sampling transect. Four current meter moorings (I to IV) were positioned along the cross-shelf transect during January and 1 mooring (I) remained in position during April (Fig. 1b). Top and bottom current meters were positioned at moorings I to IV, at depths of 17, 22, 22 and $44 \mathrm{~m}$ (top) and 50,65, 72 and $104 \mathrm{~m}$ (bottom), respectively. Water depth at each location is 65 , 98,104 and $337 \mathrm{~m}$, respectively. Mooring I is a permanent facility operated by Australian Water Technologies Ensight, and known as the Ocean Reference Station. Mooring I also records wind velocity and direction from an anemometer positioned $5 \mathrm{~m}$ above the sea surface. 
Analysis. The raw catches of each taxa were standardised to number of larvae per $100 \mathrm{~m}^{3}$. Standardised abundances were used in all statistical analyses. Similarities between larval assemblages at each sampling location were analysed by multivariate techniques.

Ichthyoplankton family abundances were fourth root transformed to enhance the contribution of less abundant taxa and a Bray-Curtis similarity matrix was generated from this data (Bray \& Curtis 1957). Similarities between assemblages were graphically represented by non-metric multidimensional scaling (MDS, Clarke 1993). MDS ordinations may be arbitrarily rotated and so axes are not labelled. Stress values indicate how well the 2-dimensional ordinations represent relationships in multidimensional space. Stress values $<0.15$ indicate a good fit (Clarke 1993). Surface and subsurface assemblages were represented in separate MDS ordinations to assist in interpretation, and because slightly different sampling methods were used to collect surface and subsurface ichthyoplankton

Relationships between assemblage distributions and hydrological variables were examined by weighted rank correlations ('BIO-ENV' procedure, Clarke \& Ainsworth 1993). A set of 9 hydrological variables was recorded for each haul. These were (1) average haul depth, (2) bathymetric depth, (3) distance from shore, (4) average temperature during haul, (5) temperature variance during haul, (6) average salinity during haul, (7) sampling date, (8) depth of mixed layer, and (9) average haul depth relative to base of mixed layer. Euclidean distance similarity matrices were generated from all possible combinations of the above 9 variables for each sampling period. Rank correlations between each of these matrices and monthly biological similarity matrices were calculated. The combination of hydrological variables resulting in the maximum correlation was considered the 'best explanation' for the observed biological pattern. This technique is an exploratory tool and its assumptions do not allow a test of significance. Full details of this analysis are given by Clarke \& Ainsworth (1993).

Heirachical agglomerative clustering was used to group monthly samples into several ichthyoplankton assemblage groupings. January and April samples were arbitrarily clustered at a 40 and $30 \%$ level of similarity, respectively, to provide a small number of groups which would function as conservative indicators of assemblage variability. Differences in taxonomic composition between groups were assessed by similarity percentages analysis (SIMPER), which determined the percentage contribution of individual taxa to the dissimilarity between groups (Clarke 1993).

Current meter data was preprocessed by resolving currents into principle along-shore and cross-shelf directions. Currents from each meter were rotated so as to align them with the bathymetry, which runs in an approximately northeast-southwest direction. Principle currents were then lowpass filtered using a Lanczos-cosine filter with a cutoff period of $2 \mathrm{~h}$ to remove high frequency contributions. Lowpassed currents were then decimated to hourly records. 24 h averages of cross-shelf current velocity and direction were also calculated for the midnight-midnight period prior to each sampling night. The magnitude of cross-shelf components are significantly smaller than along-shore components and caution must be exercised when interpreting cross-shelf flows, since a small error in the principle directions will contaminate the cross-shelf components. A time series of wind stress data was generated using the method of Large \& Pond (1981). The filtering and decimating routines applied to current data were also applied to wind data.

Surface ichthyoplankton and hydrography have been discussed in an earlier paper by Dempster et al. (1997) but have been included here for comparison.

\section{RESULTS}

\section{Factors influencing assemblage distributions}

MDS ordinations of similarities between assemblages each month revealed trends in community distributions corresponding to spatial position (Figs. 2 \& 3). In other words, assemblages close in geographical space (measured by cross-shelf position and haul depth) were also close in multidimensional space. However, the distribution of some assemblages, which have been circled in each plot, clearly do not conform to this pattern. In January, the shallow, Stn D assemblage (D3), which was sampled on January 25, was more similar to deep assemblages from shelf Stns B and $C$ than to other shallow assemblages from offshore Stns D or $E$ (Fig. 2). In April, 2 surface assemblages from Stn B, both sampled on April 8, were more similar to offshore surface samples from Stns C, D or E than to other inshore samples from Stris A or B (Fig. 3).

Results of rank correlations between assemblage similarity matrices and physical variable matrices showed the importance of depth and distance from shore, but suggested that hydrography was also an important influence on assemblage distributions (Table 2). In January, maximum correlations were obtained by correlating surface assemblage similarities with a matrix of temperature, distance from shore and depth relative to base of mixed layer $(r=0.56)$, and subsurface assemblage similarities with a matrix of temperature, distance from shore, depth relative to base of mixed layer and haul depth ( $r=0.69$ ). In April, 


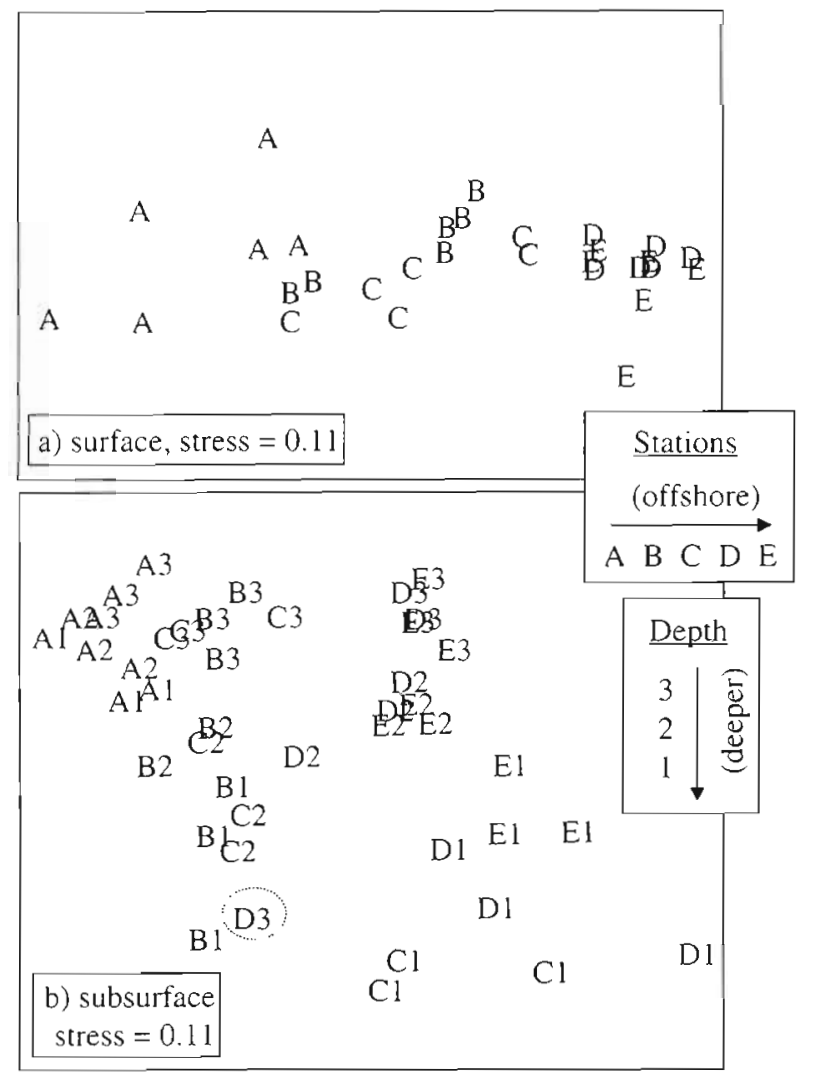

Fig. 2. Two-dimensional MDS ordinations of Bray-Curtis similarities between ichthyoplankton assemblages sampled in January 1994. (a) Surface assemblages, (b) subsurface assemblages. Relationships between assemblages are largely ordered by sampling depth and distance from shore, with a notable exception occurring at Stn $D$, in net 3 (shallow) on January 25 (circled)

maximum correlations were obtained by correlating surface assemblage similarities with a matrix of temperature alone $(r=0.66)$, and subsurface assemblage similarities with a matrix of temperature, distance from shore and haul depth $(\mathrm{r}=0.61)$

Distance from shore featured in 3 of the 4 correlations and haul depth featured in both correlations with subsurface assemblages, confirming that spatial coordinates were partial descriptors of assemblage vari-

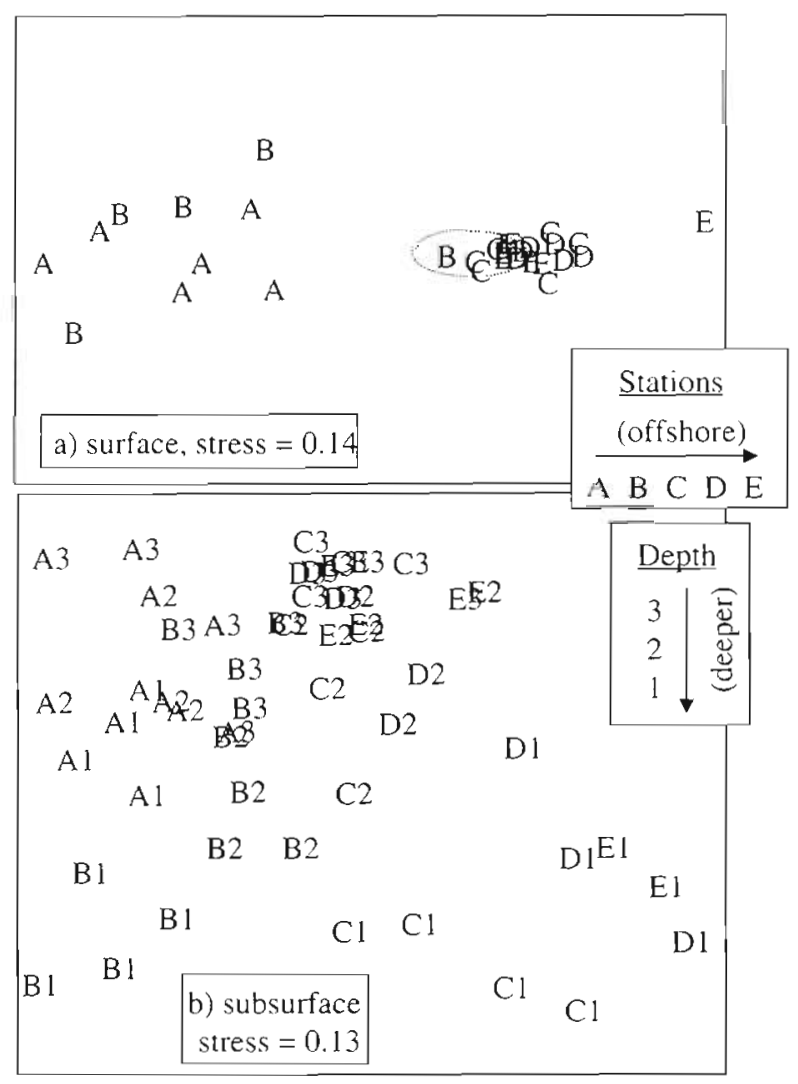

Fig. 3. Two-dimensional MDS ordinations of Bray-Curtis similarities between ichthyoplankton assemblages sampled in April 1994. (a) Surface assemblages, (b) subsurface assemblages. Relationships between assemblages are largely ordered by sampling depth and distance from shore, with notable exceptions occurring at the surface at $\operatorname{Stn} B$ on April 8 (circled)

ability. Temperature was the only variable present in all of the above maximum correlations. The other physical variable, distance from the base of the mixed layer, featured only in January correlations. January was a period of greater vertical instability than April. During April, the depth of the mixed layer was less variable within and between nights and therefore a less likely source of ichthyoplankton variability at this time.

Table 2. Results of BIOENV analysis, listing combination of hydrographic variables providing the 'best explanation' for similarities among ichthyoplankton assemblages. ('Best explanation' = highest correlation with ichthyoplankton similarity matrix)

\begin{tabular}{|llcl|}
\hline Month & $\begin{array}{l}\text { Sampling } \\
\text { depth }\end{array}$ & $\begin{array}{c}\text { Maximum } \\
\text { r value }\end{array}$ & Hydrographic matrix variables of maximum correlation \\
\hline January & Surface & 0.56 & Temperature, distance from shore, depth relative to base of mixed layer \\
& Subsurface & 0.69 & Temperature, distance from shore, depth relative to base of mixed layer, haul depth \\
April & Surface & 0.66 & $\begin{array}{l}\text { Temperature } \\
\end{array}$ \\
& Subsurface & 0.61 & Temperature, distance from shore, haul depth \\
\hline
\end{tabular}




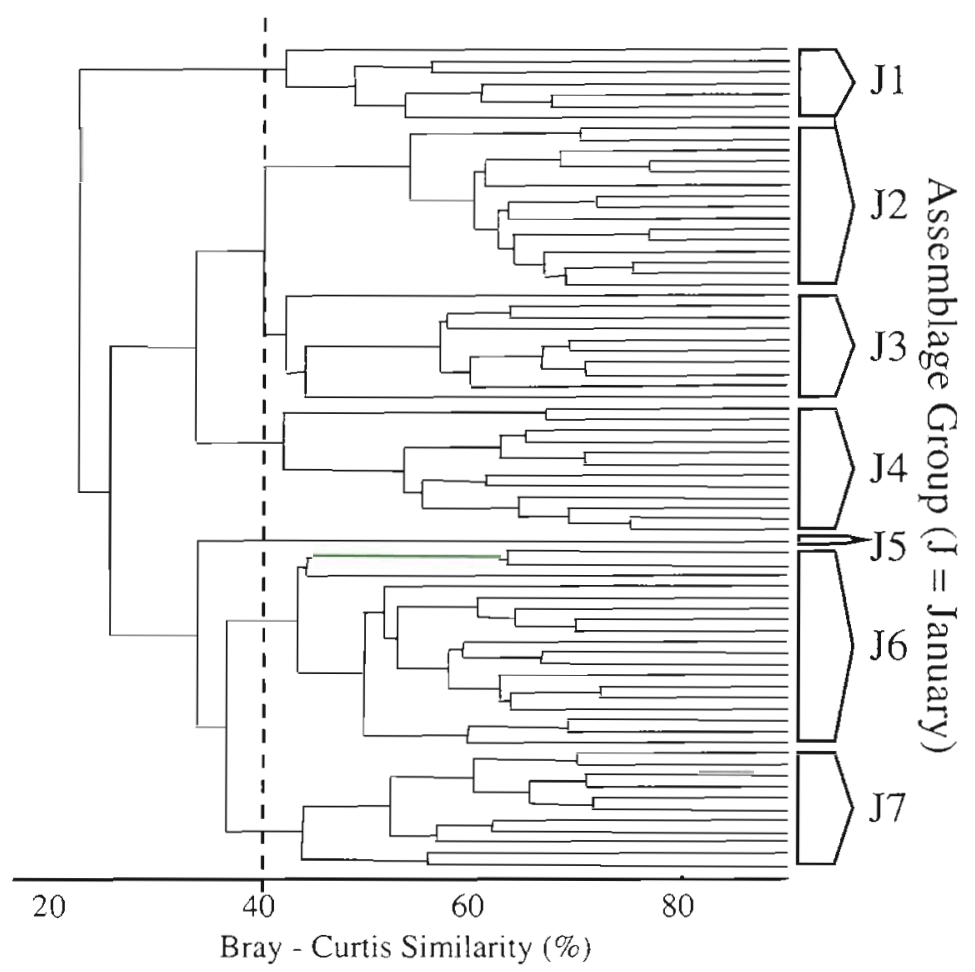

Fig. 4. Cluster dendrogram illustrating derivation of ichthyoplankton assemblage groups in January, 1994, by grouping assemblages at $>40 \%$ Bray-Curtis similarity

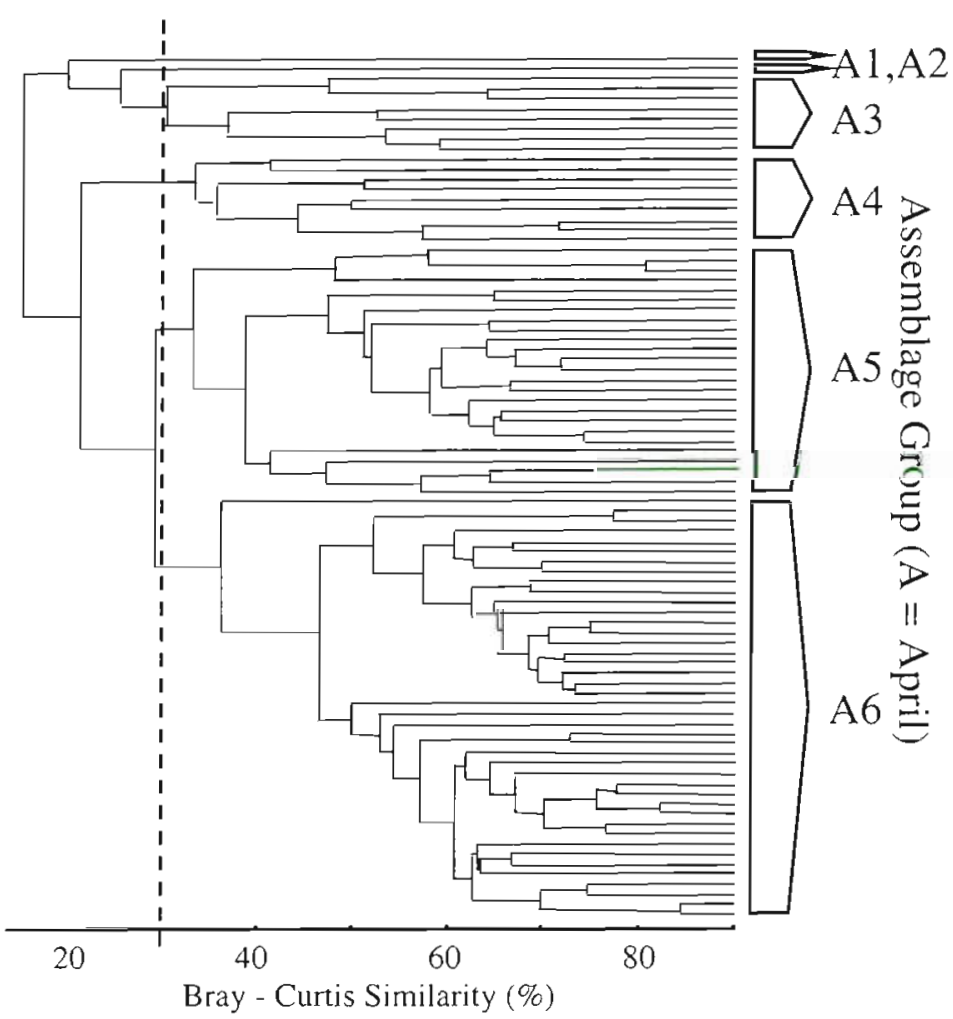

Fig. 5. Cluster dendrogram illustrating derivation of ichthyoplankton assemblage groups in April, 1994, by grouping assemblages at $>30 \%$ Bray-Curtis similarity

\section{Composition of ichthyoplankton groups}

The ichthyoplankton assemblages represented in the MDS ordinations were clustered into 7 groups in January and 6 groups in April (Figs. 4 \& 5). Groups were characterised by both taxonomic composition and total ichthyoplankton density (Table 3). Information regarding adult distributions and spawning locations is taken from Kailola et al. (1993) and Gommon et al. (1994).

In January, group J1 assemblages were characterised by low total larval density $(<50$ larvae per $100 \mathrm{~m}^{3}$ ) and occurred in deep waters, below the thermocline, over the outer shelf and slope (Table 3). The small number of larvae which occurred in this region were predominantly oceanic taxa, such as myctophids, gonostomatids and paralepidids. Groups $\mathrm{J} 2$ and $\mathrm{J} 4$ comprised assemblages of high density ( $>500$ larvae per $100 \mathrm{~m}^{3}$ ). These groups occurred in subsurface waters above or in the thermocline. Group J2, which occurred over the shelf, was distinguished by an abundance of coastally and shelf spawned larvae, including carangids, clupeids, berycids and sillaginids. Group J4, which occurred over the slope, was distinguished by an abundance of mesopelagic taxa, including myctophids, gonostomatids, paralepidids and Howella spp. Group J4 also included numerous labrids, which may have been spawned in temperate or tropical coastal waters. Group J3 contained assemblages of medium larval density, which occurred in deeper waters of the mid-shelf region. The taxa which characterised these assemblages, triglids, callionymids and morids, occur as demersal adults of inshore and offshore regions.

In January, all surface groups (J5 to J7) were characterised by low total densities. Group J5 consisted of one assemblage (sampled at Stn A) and was distinguished by the presence of pomacentrids and girellids, which spawn in the very nearshore zone. Group J6 assemblages comprised a mixture of coastal and oceanic taxa, particularly carangids and myctophids, and were distributed across surface waters of the shelf and shelf break. Group J7 assemblages occurred in surface waters over the shelf break and slope, and were distinguished by an abundance of gonorynchids, which occur as demersal adults across the continental shelf.

In April, surface groups (A1 to A.3) were again characterised by relatively low densities 


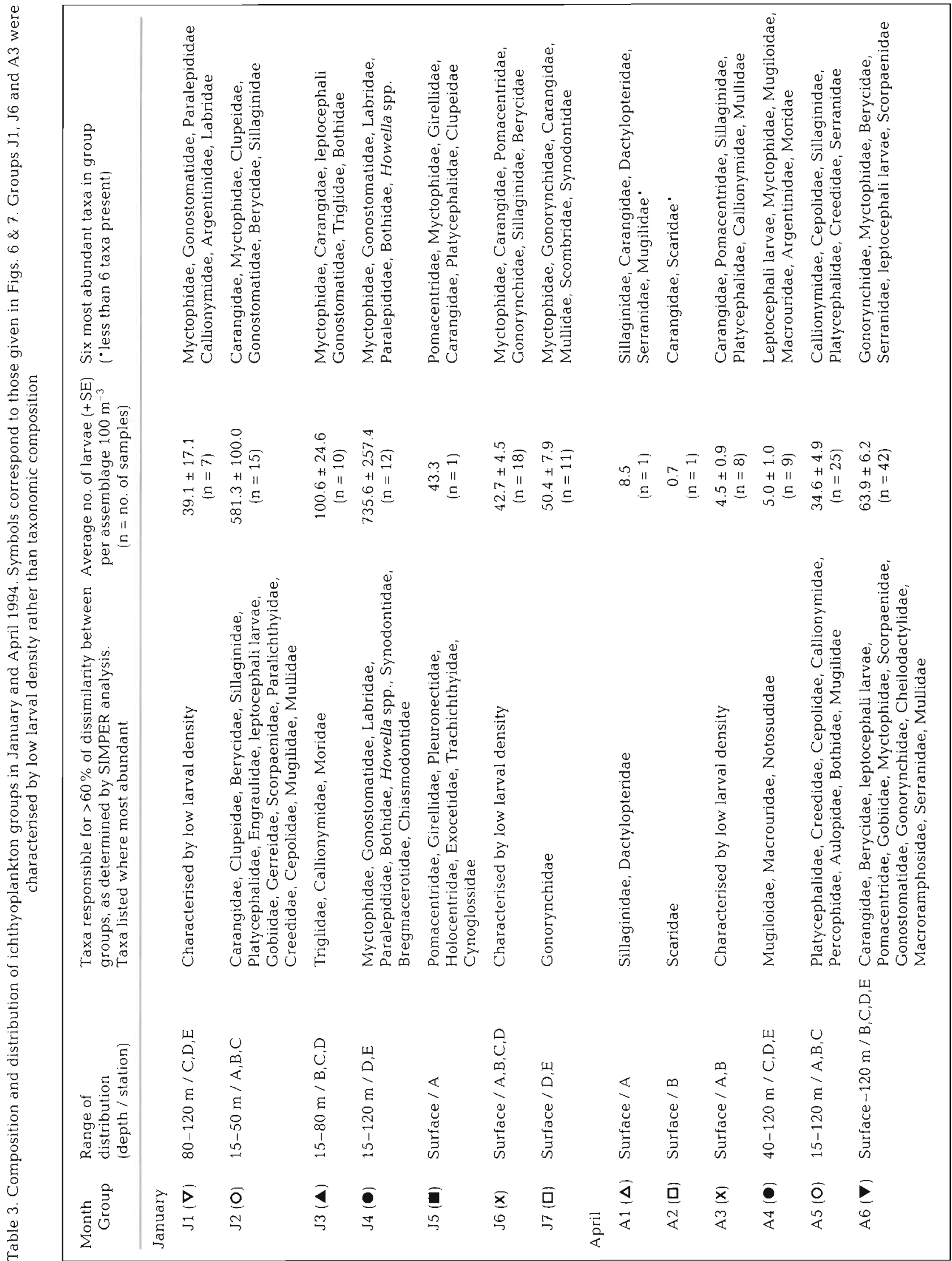


of larvae (Table 3). Groups A1 and A2 each comprised a single assemblage, sampled at Stns $A$ and $B$, respectively. The A1 assemblage was distinguished by a dominance of sillaginids, a taxon typical of the nearshore zone. The A2 assemblage was distinguished by the presence of scarids, a taxon typical of tropical waters. Group A3 comprised all other assemblages occurring in surface waters of the inner shelf, and most larvae within this group (e.g. carangids and pomacentrids) are coastally spawned. The inner shelf was not, however, the location of maximum density for any of the dominant taxa within this group, and the group was characterised by low larval density rather than taxonomic composition.

Group A4 was also characterised by assemblages of low larval density. These occurred in deep waters, in and below the thermocline, over the outer shelf and slope. The group was characterised by the presence of pinguipedids and macrourids, which occur as demersal adults over the shelf and slope, and notosudids, which are mesopelagic as adults.

Groups A5 and A6 were characterised by assemblages of relatively high total density. Group A5 assemblages occurred in subsurface waters of the inner to mid-shelf, and comprised larvae such as platycephalids, creedids, callionymids and cepolids, the adults of which occur demersally in coastal and shelf waters. Group A6 contained a large number of assemblages from surface and subsurface waters of all regions except the nearshore zone. These assemblages were characterised by the presence of coastally and shelf spawned larvae, such as carangids, berycids and pomacentrids, but also contained numerous oceanic larvae, particularly myctophids.

\section{Distribution of ichthyoplankton groups}

The distribution of groups were superimposed over shelf temperature profiles from respective sampling nights to illustrate the major features of among-night variability in the cross-shelf distribution of ichthyoplankton assemblages.

In January, a discontinuity between inshore and offshore groups occurred over the shelf break, between Stns C and D (Fig. 6b-d). The offshore distributions of surface groups, J5 and J6, and subsurface groups, J2 and $\mathrm{J} 3$, were limited to the shelf break, except on January 25 when J3 and J6 extended as far as Stn D. The shoreward distributions of surface group J7 and subsurface group J4 were also limited to the shelf break, except on January 25 when the movement of group J3 appeared to displace group J4 from Stn D. Group J3 also underwent considerable vertical displacement on January 25, rising to a depth of approximately $25 \mathrm{~m}$,

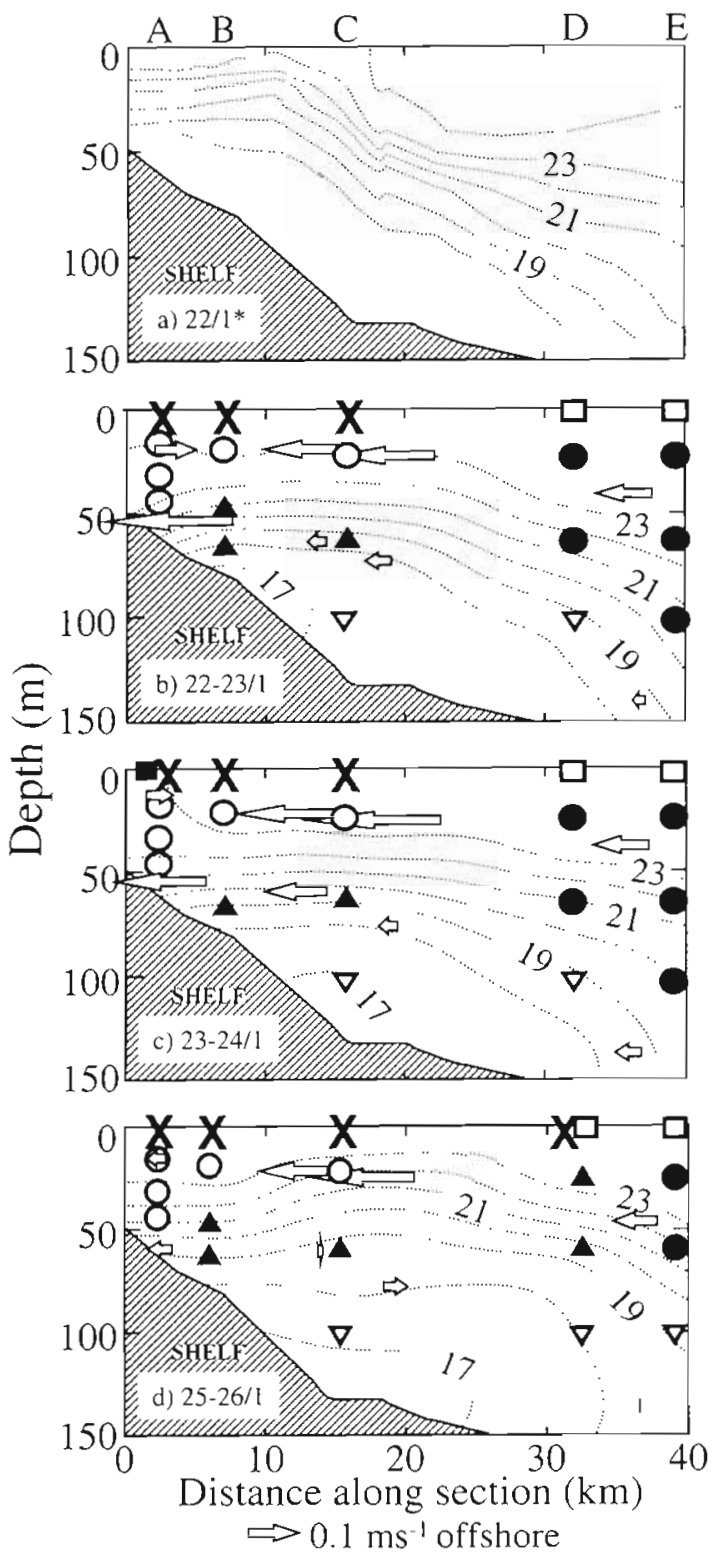

Fig. 6. Nightly distributions of ichthyoplankton assemblage groups (symbols) and averaged cross-shelf currents, superimposed over the respective nightly temperature $\left({ }^{\circ} \mathrm{C}\right)$ profiles during January, 1994. Location of sampling Stns A to E are indicated across the top of each profile. Arrows represent direction and magnitude of cross-shelf current at each current meter. ("No plankton data available prior to night of January 22, temperature profile derived from 11 CTD stations along transect during daylight hours on this date). ( $\nabla) \mathrm{J} 1_{i}$ (O) $\mathrm{J} 2_{i}$

$$
\text { (A) } \mathrm{J3} ;(\mathbf{O}) \mathrm{J} 4 \text {; (四) J5; (X) J6; (口) J7 }
$$

although this group had previously occurred at depths of $50 \mathrm{~m}$ or greater.

In April a discontinuity again occurred between inshore and offshore assemblage groups, although the location of this discontinuity was now located over the mid-shelf region, between Stns B and C (Fig. 7a-d). The offshore distributions of surface group A3, and 




Fig. 7. Nightly distributions of ichthyoplankton assemblage groups (symbols) and averaged cross-shelf currents, superimposed over the respective nightly temperature $\left({ }^{\circ} \mathrm{C}\right)$ profiles dunng April, 1994. Location of sampling Stns A to E are indicated across the top of each profile. Arrows represent direction and magnitude of cross-shelf current at each current

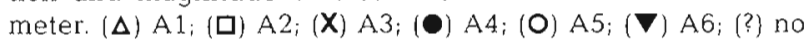
sample collected

subsurface group A5, was limited to Stn B except on April 8 (and April 7 in the case of group A5) when A3 occurred only at Stn A, and A5 extended into Stn C waters. The shoreward distribution of group $A 6$, which included surface and subsurface assemblages, was limited to Stn C, except on April 8, when this offshore group moved into Stn $B$ waters, displacing the inshore groups, A3 and A5, formerly occurring there.

\section{Within-night ichthyoplankton variability}

Within-night variability was assessed by repeated sampling at mid-shelf Stns B and $C$ between sunset on April 9 and sunrise on April 10. Sampling was conducted 4 times at each station and similarities between ichthyoplankton assemblages taken during this period are represented in MDS ordinations. Firstly, betweenstation differences in assemblages were clearly evident in both surface and subsurface waters, with Stn B assemblages grouping apart from those at Stn C (Fig. 8). At the surface, pairs of replicate samples, taken a few minutes apart, tended to be more similar to each other than to other pairs of replicate samples, taken a few hours apart within the same station (Fig. 8a). Below the surface, the 4 samples within each depth, taken over a $9 \mathrm{~h}$ period, grouped together on the MDS ordination, suggesting persistent amongdepth differences within each station during the sampling period (Fig. 8b).

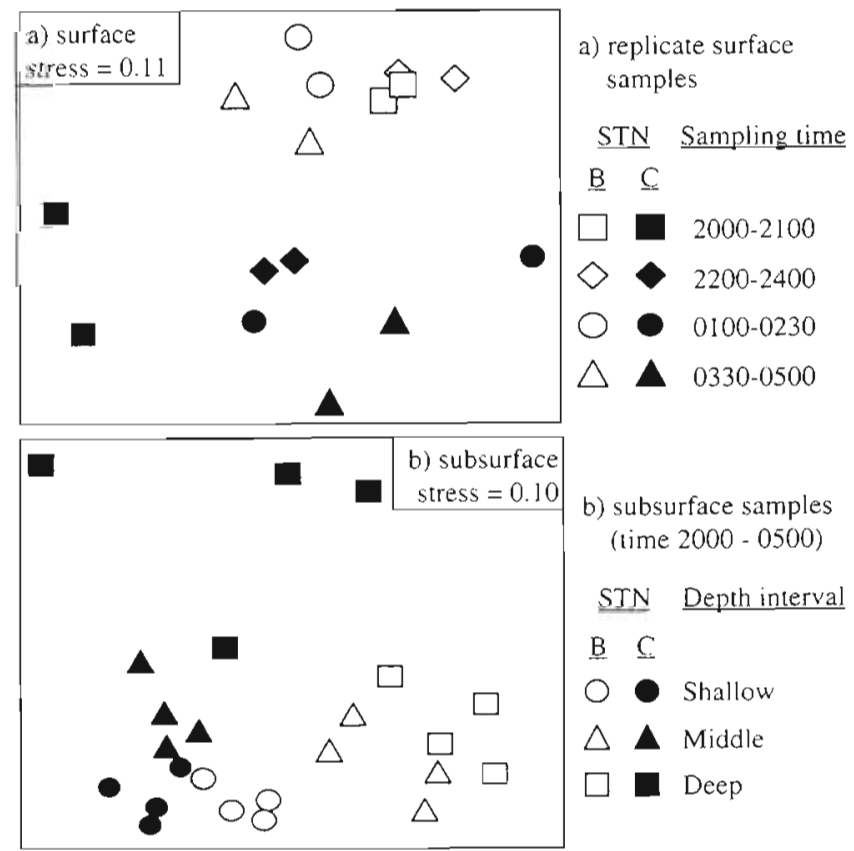

Fig. 8. Two-dimensional MDS ordinations of Bray-Curtis similarities between ichthyoplankton assemblages repeatedly sampled at Stns $B$ and $C$ to assess within-night variability. All sampling was conducted between 19:00 h, April 9, and 05:00 h, April 10, 1994. (a) Pairs of replicate surface samples,

(b) individual subsurface samples

\section{Oceanography}

A description of averaged, near-surface cross-shelf flows observed during the study periods may be found in Dempster et al. (1997). To identify processes and 
resulting transports throughout the interior of the water-column, averaged, deep cross-shelf flows were also calculated for the $24 \mathrm{~h}$ period (midnight to midnight) preceding each sampling night. These daily current averages, along with nightly, cross-shore temperature sections, were used to examine the cross-shelf current field (Figs. 6 \& 7).

A strong, warm EAC feature had encroached into Sydney slope waters immediately prior to the January sampling period (AVHRR remote sea surface temperature images, not shown). This influence was evidenced in the shelf/slope temperatures and cross-shore currents which showed a strong tilting of the isotherms, upwards towards the coast, and onshore flows over the outer shelf (Fig. 6a-d). Prior to biological sampling, there were also indications of a shelf-break front over

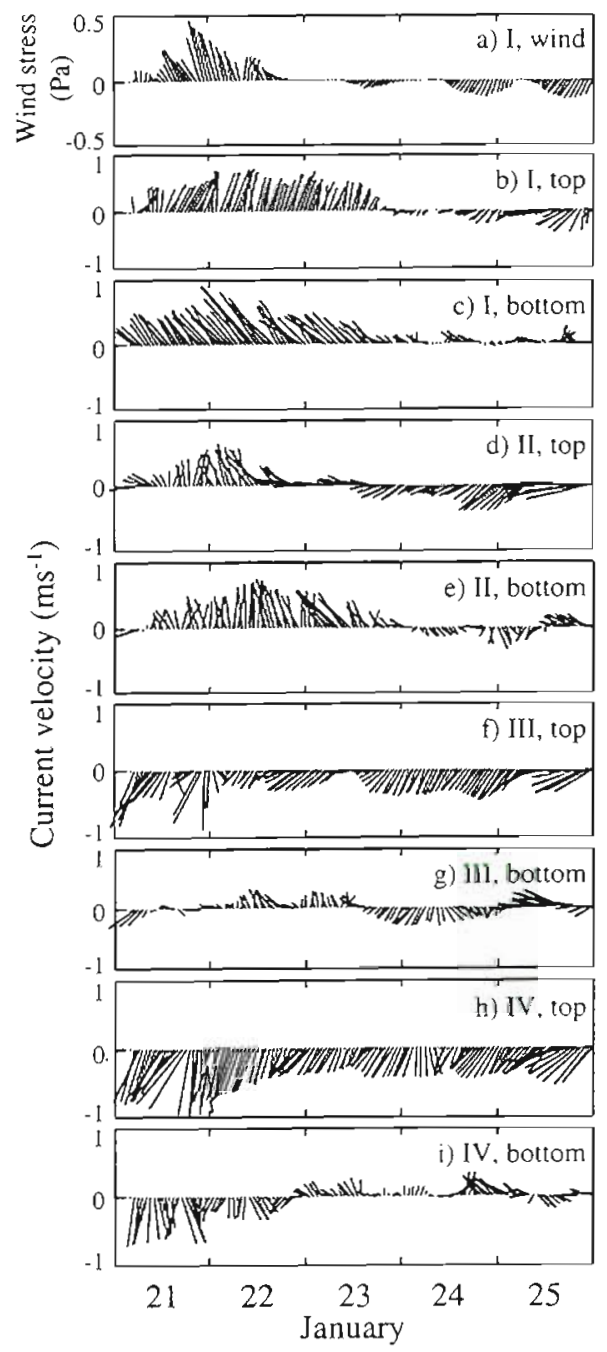

Fig. 9. Vector stick plots, January 1994. Direction of all vectors follows oceanographic conventions. Top of page is north. (a) Hourly wind stresses (Pa) at mooring I. Near-surface current velocities and bottom current velocities $\left(\mathrm{m} \mathrm{s}^{-1}\right)$ at (b), (c) mooring I; (d), (e) mooring II; (f), (g) mooring III; (h), (i) mooring IV the outer shelf where horizontal temperature stratification was evident (Fig. 6a). AVHRR images showed that the EAC feature moved back offshore during the study period. This offshore migration was reflected in the flattening out of offshore isotherms and a weakening, or reversal (deep at moorings II and III), of the outer shelf cross-shore flows during the study period.

The nearshore temperature and current fields also showed considerable variability in January. A strong northward, downwelling favourable wind event on January 21 and 22 flattened out previously upward tilting isotherms over the inner and middle shelf regions (Figs. 6a \& 9). Shoreward near-surface flow over the mid-shelf was consistent with wind and EAC forcing. Weak, offshore flow in the nearshore zone on January 22 and 23 may be an indication of forced or unforced CTW activity (Fig. 6b,c). It is probable that an offshore flow was also present in the bottom boundary layer during this period of downwelling favourable winds which may have helped to maintain the shelf-break front apparent earlier. As the wind abated on January 23, the isotherms again tilted up as the EAC became the only acting forcing process (Fig. 6b). The winds during January 23 to 25 were weak coastal sea breezes. This light forcing appeared to have little influence on shelf waters as the nearshore isotherms remained flat as both the wind and EAC forcing abated (Figs. 6d \& 9).

Hence, during the January sampling period, the cross-shore flows in the mixed layer remained mainly directed onshore. Meanwhile, the interior cross-shore flows weakened and in some cases reversed from onshore-flowing to offshore-flowing as the EAC feature migrated offshore and the isotherms relaxed to a nearly horizontal state.

The April sampling period was one of considerably greater oceanographic stability by comparison with conditions during January although, again, a strong EAC feature was influencing the shelf and slope waters. Isotherms remained relatively fixed between April 5 and 9, sloping upwards towards the coast over both the shelf and slope (Fig. 7). A dip in isotherms over the mid-shelf on April 6 may have been associated with the passage of an internal wave or baroclinic tide (Fig. 7b). Nearshore isotherm displacement corresponded to nearshore wind activity. Winds were from the north-east (upwelling favourable) between April 5 and 6 , during which time nearshore isotherms sloped upward toward the coast, but from the south (downwelling favourable) between April 7 and 8 , during which time isotherms relaxed (Figs. 7 \& 10). Current data was only available for the nearshore zone (mooring 1) in April. Between April 5 and 6 nearsurface and bottom currents were flowing offshore, but decreased in magnitude during this period 


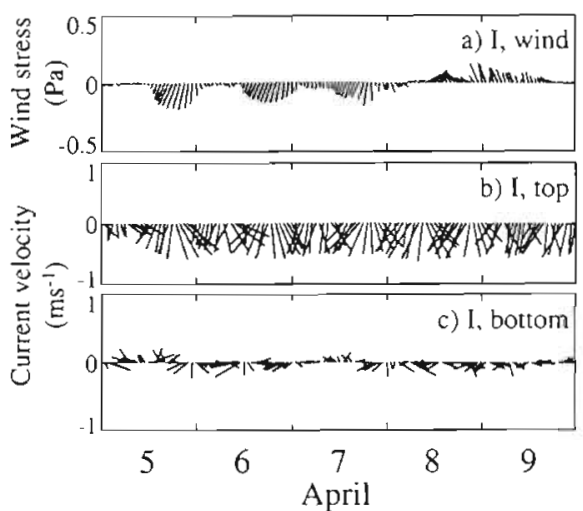

Fig. 10. Vector stick plots, April 1994. (a) Hourly wind stresses (Pa), (b) near-surface current velocities $\left(\mathrm{m} \mathrm{s}^{-1}\right)$, and (c) bottom current velocities $\left(\mathrm{m} \mathrm{s}^{-1}\right.$ ) at mooring $\mathrm{I}$. Wind and current data only available from mooring I in April

(Fig. 7a-b). Between April 7 and 8, near-surface currents (and bottom currents on April 7) flowed onshore, corresponding to the commencement of southerly winds (Figs. $7 \mathrm{c}-\mathrm{d} \& 10$ ).

\section{Ichthyoplankton and oceanography}

Considerable agreement existed between ichthyoplankton assemblage movements and water movements during both sampling periods. Firstly, on January 23 , the introduction of assemblage group J5 into Stn A waters corresponded to persistent offshore surface flow during the previous $48 \mathrm{~h}$ (Fig. $6 \mathrm{~b}-\mathrm{c}$ ). Group $\mathrm{J} 5$ consisted of taxa spawned in the very nearshore zone. The disappearance of this group on January 25 corresponded to a reversal in the near-surface current direction at this time, returning surface water (and ichthyoplankton) to the very nearshore zone (Fig. 6d).

Secondly, on January 25, the offshore and upward displacement of group $\mathrm{J} 3$, from deep shelf waters to shallow slope waters, corresponded to offshore, interior transport over the shelf and upward isotherm displacement over the shelf break (Fig. 6d). Group J3 was characterised by a medium density of larvae, and the introduction of this group into shallow slope waters resulted in a dramatic decrease in total ichthyoplankton density in a region of formerly high density.

Thirdly, on April 8, the shoreward distribution of group A6 extended into Stn B waters, displacing groups $A 3$ and $A 5$. This corresponded to the commencement of onshore, near-surface flow on April 7 , which continued during April 8 (Fig. $7 \mathrm{c}, \mathrm{d}$ ).

The assemblage variability corresponding to the latter 2 dynamic events was also evident in the monthly MDS ordinations, in which the change in assemblage type at each location has been circled (Figs. 2b \& 3a).
A feature in both study periods was the discontinuity between 'inshore' and 'offshore' groups which occurred over the shelf break in January and over the midshelf region in April. The position of this biological discontinuity did not correspond to any obvious hydrodynamic boundary in January but did correspond to the shoreward extent of the $23^{\circ} \mathrm{C}$ isotherm in April (Figs. 6 \& 7). The hydrographic regime was also reflected in similarities among surface assemblages (Figs. 2 \& 3). In January, there was a gradual continuum from Stns $A$ to $E$ in the MDS ordination of surface assemblages (Fig. 2a). However, in April, there was a sharp discontinuity between inshore assemblages (A and $\mathrm{B}$ ), which occurred in water generally $<23^{\circ} \mathrm{C}$, and offshore assemblages water (Stns $C$ to $E$, and $B$ on April 8), which occurred within water generally $>23^{\circ} \mathrm{C}$ (Fig. 3a). Furthermore, in April there was less variability among offshore assemblages than among inshore assemblages, reflecting hydrographic variability in each region.

\section{DISCUSSION}

\section{Factors influencing ichthyoplankton distributions}

There were strong vertical and horizontal trends in the distributions of ichthyoplankton assemblages over the Sydney shelf. The cross-shelf distribution of assemblages, particularly in January, was in general agreement with the presumed spawning locations of component taxa. However, assemblage distributions were also influenced by changes in hydrography. Of the environmental factors examined, a combination of spatial position (sampling depth, distance from shore), water temperature (the primary cause of density variability over the Sydney shelf) and sampling depth relative to the base of the mixed layer best explained variability in assemblage distributions during each sampling period. The significance of water column structure to Sydney shelf ichthyoplankton has been previously emphasised by the finding that highest larval density and taxonomic diversity is generally associated with the interface between mixed layer and thermocline, and longer term (between-month) changes in the location of this interface correspond to longer term changes in vertical and cross-shelf distributions (Smith \& Suthers 1999).

\section{Among-night ichthyoplankton variability}

In the Sydney shelf region, considerable vertical, cross-shelf and longshore movement of water may occur over a 24 h period (Huyer et al. 1988, Griffin \& 
Middleton 1991). The correlation of ichthyoplankton distributions with hydrographic features here and in earlier work, suggested that these short term changes in hydrography may result in concurrent shifts in larval fish distributions.

There was, indeed, a high level of agreement between observed ichthyoplankton variability and among-night variability in the cross-shelf temperature and current fields. The between-night movement of surface and subsurface assemblages, at both inshore and offshore locations, followed paths that might be expected of passively drifting particles responding to cross-shelf circulation. The high level of agreement was remarkable, considering our assumption of negligible along-shore variability. The cross-shelf currents over the Sydney shelf (and other shelves) are often nearly an order of magnitude less than the along-shore currents (Middleton 1987). This disparity between the magnitudes of cross-shelf and along-shore currents places an upper bound on the validity of simple, 2 dimensional, cross-shore studies of around $1 \mathrm{wk}$ before the assumption of no along-shore variability becomes invalid. Over longer periods, planktonic organisms may be advected along-shore over distances greater than the characteristic along-shore length scales of most dynamic processes. The good biological-physical agreement found in our study, and by Dempster et al. (1997), was thus partly due to the relatively short study periods, as well as the high cross-shelf resolution of sampling.

The ichthyoplankton assemblages presented here function as short term, biological tracers of physical processes across the continental shelf. In earlier observations of Sydney shelf surface ichthyoplankton, good agreement was found between nightly changes in hydrography and ichthyoplankton distributions (Dempster et al. 1997) although results of the present study indicate that these surface communities are often taxonomically distinct from adjacent communities below the surface. Previous agreement has also been found between monthly changes in hydrography and subsurface ichthyoplankton distributions (Smith \& Suthers 1999). However, the results of the present study indicate that both surface and subsurface ichthyoplankton assemblages show an almost immediate response to physical forcing, and that observations of ichthyoplankton distributions are likely to reflect very recent hydrodynamic regimes.

The responses of assemblages to physical forcing observed during this study were consistent with passive transport, which does not, however, constitute evidence for a lack of larval behaviour. The maintenance of larval position within a well defined, hydrographic region may sometimes be consistent with the distribution of passive particles, although behaviour, such as diurnal migration or responses to hydrographic cues, may still occur within that region (e.g. Lobel \& Robinson 1986, Kim \& Kendall 1989). Regardless of the underlying mechanisms, however, the similarity between ichthyoplankton responses to hydrodynamic variability and that predicted for passive dispersal is likely to be a useful feature in explaining, or predicting, short term ichthyoplankton variability.

\section{A coastal retention mechanism?}

Our observations suggest several physical processes may lead to the retention or recirculation of ichthyoplankton over the Sydney shelf. Firstly, ichthyoplankton over the shelf appears to be primarily distributed within the mixed layer and upper thermocline (Smith \& Suthers 1999). This general pattern of vertical distribution appears to be maintained both night and day (Smith unpubl. data). Over the mid-outer shelf, crossshelf currents at these depths are predominantly onshore during EAC intrusion events. Hence, the maintenance of this vertical position may be sufficient to transport and retain many plankton organisms within inner-mid shelf waters. Near-surface organisms could experience further shoreward transport during onshore, mixed layer, Ekman transport during coastal downwelling events.

Near-surface processes are probably sufficient to retain the majority of ichthyoplankton within the shelf region. However, some ichthyoplankton were observed in deeper shelf waters. The deep distribution of some larval taxa corresponded to the deep distribution of adults of these species. The vertical position of these larvae was, therefore, likely to be typical and reflect spawning locations. Occasional individuals of other taxa were also found in deep samples, representing less typical distributions for these species. Such larvae may have been accidentally entrained by physical processes over the shelf. For example, deepening of the mixed layer in response to strong downwelling favourable winds would encourage mixing between the surface and interior and could entrain some larvae. A second physical mechanism may assist in retaining these deeply distributed larvae within shelf waters. Results from this study suggest that the concurrent action of a downwelling favourable wind and the EAC may lead to a closed recirculation cell across the shelf (Fig. 11). This would act as follows: (1) surface layer onshore flow as a result of surface Ekman drift forced by local wind stress and the onshore flow typically associated with EAC encroachment events; (2) interior and bottom boundary layer offshore return flow as a result of the wind-driven downwelling circulation; (3) the recirculation cell would be completed by verti- 


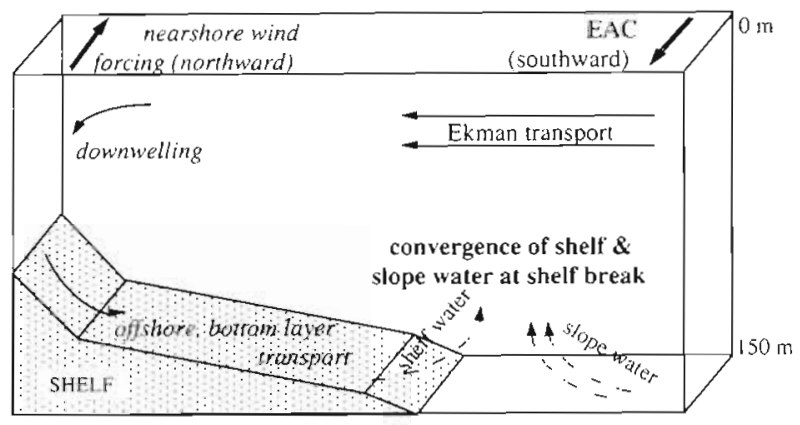

Fig. 11. Schematic of cross-shelf recirculation cell. Recirculation of shelf water proposed to occur through the concurrent action of downwelling-favourable winds and EAC encroachment events

cal transports and mixing over the shelf-break within a turbulent shelf-break front forced by the convergence of offshore shelf flows and onshore, EAC-driven, deeper slope flows.

Conclusive proof of the existence of such a recirculation cell will only come from further numerical and observational studies, which are currently underway. Existing evidence suggests that both persistent downwelling-favourable winds and EAC-driven, onshore flow commonly occur during summer (McClean-Padman \& Padman 1991). Summer is the peak period of ichthyoplankton abundance over the shelf and a period of high plankton productivity in general (Dakin \& Colefax 1933, Bruce 1982, Hallegraeff \& Jeffrey 1993, Smith \& Suthers 1999).

The duration of a dynamic event, such as the proposed recirculation cell, in the coastal ocean is likely to be considerably shorter than the duration of an entire ichthyoplanktonic larval phase, during which time other biological and physical factors may also influence larval distributions. However, the intensity of a dynamic event may be of such magnitude that it is still the most significant factor influencing individual larval dispersal. Anomalous, short term, advective processes appear to be significant factors in the recruitment of many coastal species with a planktonic larval phase (Cowen 1985, 1993, Cowen et al. 1993, Thorrold et al. 1994, Jenkins et al. 1997). Importantly, the entire larval population need not be exposed to a particular physical process to facilitate 'successful' recruitment. Unpredictable, relatively infrequent events such as that observed at the Sydney shelf-break in January 1994, may modify the distribution of only some larvae, but it may be these individuals that constitute the recruiting population to the shelf.

The alongshore advection of larvae would also occur during such events. Near-surface, alongshore currents over the outer Sydney shelf are primarily southward in response to $\mathrm{EAC}$ forcing and current velocities of greater than $1 \mathrm{~m} \mathrm{~s}^{-1}$ are common (Gibbs et al. 1998). In contrast, nearshore currents are typically weaker and the direction of near-surface, alongshore currents over the inner shelf fluctuate in response to nearshore winds, coastal-trapped waves and EAC intrusion events. Thus, expected net alongshore transport in the nearshore zone would be considerably less than on the outer shelf. At an average nearshore velocity of around $0.1 \mathrm{~m} \mathrm{~s}^{-1}$ southward, a larvae would be advected approximately $240 \mathrm{~km}$ after $1 \mathrm{mo}$ in the plankton. The same period spent over the outer shelf could advect a larvae several times this distance. In this way, physical processes which transport ichthyoplankton shoreward may also minimise longshore drift.

\section{Implications}

The results obtained here are significant, firstly, as a guide to future studies of ichthyoplankton variability, in the choice of effective sampling scales and in the type of data which should be collected. Secondly, our results provide further insights into the importance of physical mechanisms in the retention/dispersal of planktonic organisms of continental shelf regions.

It is clear that, during the study period, within-night ichthyoplankton variability was less than among-night variability, indicating that our conclusions are robust, and that our sampling regime is effective for a large spatial scale study of this nature. The spatial scale, i.e. the entire cross-shelf region, is important because it is at this scale that major distributional trends may be observed in ichthyoplankton communities and also at this scale that relevant dynamic processes are operating. Implications for future studies which attempt to explain ichthyoplankton variability are clear. Even in cases where the area of interest is small, e.g. a few kilometres, as in the assessment of a localised environmental impact, physical and biological data should be collected over a larger spatial scale because the sources of small scale ichthyoplankton variability include numerous large scale physical processes.

Our simple, 2-dimensional approach, which ignored longshore variability, proved adequate in examining short term, cross-shelf variability. Rates of longshore advection and the characteristic along-shore lengths of most dynamic processes in the coastal ocean tend to ensure longshore variability will be minimal within relatively short study periods. Within observational periods greater than $1 \mathrm{wk}$, longshore variability could be a confounding influence. Within our study periods of $4 \mathrm{~d}$, we found a high level of agreement between observed ichthyoplankton variability and cross-shelf hydrodynamic variability. 
As predicted, ichthyoplankton assemblages functioned as short term, biological tracers of water movement over the shelf. This seemingly passive response of ichthyoplankton to physical forcing may prove a useful feature in future attempts to model large scale, short term ichthyoplankton dispersal. At smaller spatial scales, or longer temporal scales, there may be less agreement between ichthyoplankton and hydrodynamic variability, due to the potential influence of biological factors. In particular, the early stage of development (preflexion and flexion) and small size $(<10 \mathrm{~mm})$ of most larvae encountered in this study is likely to have encouraged passive dispersal (Smith unpubl. data). Over longer temporal scales, larval behaviour may modify the cross-shelf distribution of some taxa.

Cross-shelf, advective processes observed during our study, including the recirculation of shelf water, may represent significant mechanisms for the retention/dispersal of many shelf-spawned or coastallyrecruiting larvae of fish and other organisms. Whilst our observations do not exclude the possibility of larval behaviour in the shelf region, the existence of physical mechanisms which retain neutrally buoyant particles over the shelf and minimise longshore drift suggests that the influence of behaviour could be of secondary importance for larval dispersal/retention in this shelf region.

Acknowledgements. We thank Dr A. Miskiewizc for many hours spent assisting with identifications, D. Rissik for thought-provoking discussions and assistance with analyses, and anonymous reviewers for helpful criticism. We gratefully acknowledge the support provided by the captain and crew of the RV 'Franklin' Funding was provided by an Austratian Research Council small grant to I.M.S.

\section{LITERATURE CITED}

Bray JR, Curtis JT (1957) An ordination of the upland forest communities of southern Wisconsin. Ecol Monogr 27. $325-349$

Bruce BD (1982) A seasonal study of ichthyoplankton at two coastal stations off Port Hacking. MSc thesis, University of NSW

Castillo GC, Li HL, Golden JT (1994) Environmentally induced recruitment variation in petrale sole, Eopsetta jordani. Fish Bull 92:481-493

Clarke KR (1993) Non-parametric multivariate analysis of changes in community structure. Aust J Ecol 18:117-143

Clarke KR, Ainsworth M (1993) A method of linking multivariate community structure to environmental variables. Mar Ecol Prog Ser 92:205-219

Condie SA (1995) Interactions between western boundary currents and shelf waters: a mechanism for coastal upwelling. J Geophys Res 100:24811-24818

Cowen RK (1985) Large scale pattern of recruitment by the labrid, Semicossyphus pulcher: causes and implications. J Mar Res 43:719-742
Cowen RK, Hare JA, Fahay MP (1993) Beyond hydrography: can physical processes explain larval fish assemblages within the middle Atlantic Bight? Bull Mar Sci 53:567-587

Csanady GT (1989) Energy dissipation and upwelling in a western boundary current. J Phys Oceanogr 19:462-473

Dakin WJ, Colefax AN (1933) The marine plankton of the coastal waters of New South Wales. I. The chief planktonic forms and their seasonal distribution. Proc Linn Soc NSW 58:186-222

Dempster T, Gibbs MT, Rissik D, Suthers IM (1997) Beyond hydrography: daily ichthyoplankton variability and short term oceanographic events on the Sydney continental shelf. Cont Shelf Res 17:1461-1481

Fechhelm RG, Bryan JD, Griffiths WB, Wilson WJ, Gallaway BJ (1994) Effect of coastal winds on the summer dispersal of young least cisco (Coregonus sardinella) from the Colville River to Prudhoe Bay, Alaska: a simulation model. Can J Fish Aquat Sci 51:890-899

Frank KT, Loder JW, Carscadden JE, Leggett WC, Taggart CT (1992) Larval flatfish distributions and drift on the Southern Grand Bank. Can J Fish Aquat Sci 49:467-483

Gibbs MT, Marchesiello P, Middleton JH (1997) Nutrient enrichment of Jervis Bay, Australia, during the massive 1992 coccolithophorid bloom. Mar Freshwat Res 48: $473-478$

Gibbs MT, Middleton JH (1997) Barotropic and baroclinic tides on the Sydney continental shelf. Cont Shelf Res 17 $1005-1027$

Gibbs MT, Middleton JH, Marchesiello P (1998) Baroclinic response of Sydney shelf waters to local wind and deep ocean forcing. J Phys Oceanogr 28:178-190

Gommon MF, Glover JCM, Kuiter RH (1994) The fishes of Australia's south coast. State Print, Adelaide

Gray CA, Otway NM, Laurenson FA, Miskiewicz AG, Pethebridge RL (1992) Distribution and abundance of marine fish larvae in relation to effluent plumes from sewage outfalls and depth of water. Mar Biol 113:549-559

Gray CA (1993) Horizontal and vertical trends in the distributions of larval fishes in coastal waters off central New South Wales, Australia, Mar Biol 116:649-666

Gray CA (1996a) Do thermoclines explain the vertical distributions of larval fishes in the dynamic coastal waters of south-eastern Australia? Mar Freshwat Res 47:183-190

Gray CA (1996b) Small-scale temporal variability in assemblages of larval fishes: implications for sampling. J Plankton Res 18:1643-1657

Griffin DA, Middleton JH (1991) Local and remote wind forcing of New South Wales inner shelf currents and sea level. J Phys Oceanogr 21:304-322

Hallegraeff GM, Jeffrey SW (1993) Annually recurrent diatom blooms in spring along the New South Wales coast of Australia. Aust J Mar Freshwat Res 44:325-334

Hare JA, Cowen RK (1991) Expatriation of Xyrichtys novacula (Pisces: Labridae) larvae: evidence of rapid cross-slope exchange. J Mar Res 49:801-823

Huyer A, Smith RL, Stabeno PJ, Church JA, White NJ (1988) Currents off south-eastern Australia: results from the Australian coastal experiment. Aust J Mar Freshwat Res 39: $245-288$

Jenkins GP, Black KP, Wheatley MJ, Hatton DN (1997) Temporal and spatial variability in recruitment of a temperate, seagrass-associated fish is largely determined by physical processes in the pre- and post-recruitment phases. Mar Ecol Prog Ser 148:23-35

Kailola P, Williams MJ, Stewart PC, Reichelt RE, McNee A, Greeve C (1993) Australian Fisheries Resources. Bureau of Resource Sciences, Canberra 
Kim S, Kendall AW Jr (1989) Distribution and transport of larval walleye pollock (Theragra chalcogramma) in Shelikof Strait, Gulf of Alaska, in relation to water movement. Rapp PV Reun Cons Int Explor Mer 191:127-136

Large WS, Pond S (1981) Open ocean momentum flux measurements in moderate to strong winds. J Phys Oceanogr $11: 324-336$

Lobel PS, Robinson AR (1986) Transport and entrapment of fish larvae by ocean mesoscale eddies and currents in Hawaiian waters. Deep-Sea Res 33:483-500

Lochmann SE, Taggart CT, Griffin DA, Thompson KR, Maillet GL (1997) Abundance and condition of larval cod (Gadus morhua) at a convergent front on Western Bank, Scotian Shelf. Can J Fish Aquat Sci 54:1461-1479

Middleton JH (1987) Sydney deepwater outfalls environmental monitoring program pilot study. Volume 2, Oceanographic component. Manly Hydraulics Laboratory, Sydney

McClean-Padman J, Padman L (1991) Summer upwelling on the Sydney inner continental shelf: the relative roles of local wind forcing and mesoscale eddy encroachment. Cont Shelf Res 11:321-345

Nilsson CS, Cresswell GR (1981) The formation and evolution of East Australian Current eddies. Prog Oceanogr 9: 133-183

Olivar MP, Beckley LE (1994) Influence of the Agulhas Current on the distribution of lanternfish larvae off the south-

Editorial responsibility: Otto Kinne (Editor),

Oldendorf/Luhe, Germany east coast of Africa. J Plankton Res 16:1759-1780

Olivar MP, Shelton PA (1993) Larval fish assemblages of the Benguela Current. Bull Mar Sci 53:450-474

Parrish RH, Nelson CS, Bakun A (1981) Transport mechanisms and reproductive success of fishes in the California Current. Biol Oceanogr 1:175-203

Polacheck T, Mountain D, McMillan D, Smith W, Berrien P (1992) Recruitment of the 1987 year class of Georges Bank haddock (Melanogrammus aeglefinus): the influence of unusual larval transport. Can $J$ Fish Aquat Sci 49:484-496

Sabates A. Maso M (1992) Unusual larval fish distribution pattern in a coastal zone of the western Mediterranean Limnol Oceanogr 37:1252-1260

Sabates A, Olivar MP (1996) Variations of larval fish distribution associated with variability in the location of a shelfslope front. Mar Ecol Prog Ser 135:11-20

Smith KA, Suthers IM (1999) Displacement of diverse ichthyoplankton assemblages by a coastal upwelling event on the Sydney shelf. Mar Ecol Prog Ser 176:49-62

Sponaugle S, Cowen RK (1996) Nearshore patterns of coral reef fish larval supply to Barbados, West Indies. Mar Ecol Prog Ser 133:13-28

Thorrold SR, Shenker JM, Mojica R, Maddox ED, Wishinski E (1994) Temporal patterns in the larval supply of summerrecruiting reef fishes to Lee Stocking Island, Bahamas. Mar Ecol Prog Ser 112:75-86

Submitted: June 22, 1998; Accepted: October 22, 1998

Proofs received from author(s): March 5, 1999 